\title{
Surveillance of nosocomial infections in Dr. Cipto Mangunkusumo National General Hospital, Jakarta, 1999-2002
}

\author{
Djoko Widodo*, Dalima Astrawinata ${ }^{f}$
}

\begin{abstract}
Abstrak
Infeksi nosokomial merupakan salah satu masalah utama di rumah sakit yang berkaitan dengan morbiditas, mortalitas dan peningkatan biaya kesehatan. Survilens sebaiknya dilakukan berkala untuk mendapatkan data tentang insiden infeksi nosokomial, jenis infeksi, patogen dan pola resistensi. Kami melaporkan hasil surveilens nosokomial di Rumah Sakit Umum Pusat Nasional (RSUPN) Dr. Cipto Mangunkusumo, Jakarta, antara tahun 1999 hingga 2002. Data didapatkan dari surveilens yang dilakukan oleh Panitia Pengendalian Infeksi Rumah Sakit. Surveilens dilakukan terhadap pasien dengan risiko infeksi nosokomial seperti menjalani prosedur bedah, kateter urin, kateter vena perifer atau sentral, ventilator dan prosedur invasif lainnya. Kriteria infeksi nosokomial yang digunakan berdasarkan Pedoman dan Petunjuk Teknis Panitia Pengendalian Infeksi Nosokomial RSUPN Dr. Cipto Mangunkusumo tahun 1999 yang mengacu pada definisi CDC mengenai infeksi nosokomial. Insiden infeksi nosokomial pada tahun 1999, 2000, 2001 dan 2002 adalah 1,1;0,9;0,6 dan 0,4\%. Jenis infeksi nosokomial mencakup infeksi kateter, luka operasi, saluran kemih dan saluran pernapasan berkisar antara 0 hingga 5,6 \%. Bakteri Gram negatif terdiri dari Pseudomonas sp, Enterobakter aerogenes, Eskherishia koli, Proteus mirabilis merupakan patogen tersering. Bakteri Gram positif terdiri dari Staphylococcus epidermidis, Stafilokokus aureus dan Streptokokus anhemolitikus. Didapatkan pada surveilens ini kecenderungan insiden infeksi nosokomial bakteri Gram positif. Sebagian besar bakteri Gram negatif telah resisten terhadap penisilin, amoksisilin-asam klavulanat dan sefalosporin generasi ke-3, tetapi masih sensitif terhadap sefalosporin generasi ke-4 dan aminoglikosida. Bakteri Gram positif masih sensitif terhadap penisilin, amoksisilin-asam klavulanat, sefalosporin generasi ke-4 dan aminoglikosida. (Med J Indones 2004; 13: 107-12)
\end{abstract}

\begin{abstract}
Nosocomial infection are one of the main problem in hospital which are associated with significant morbidity, mortality and increased economic cost. Surveillance should be attempted regularly to obtain local data of incidence of nosocomial infections, types of infection, pathogen and resistance pattern. We reported the results of nosocomial surveillance in Dr. Cipto Mangunkusumo National General Hospital, Jakarta, in year 1999 to 2002. The data were obtained from surveillance, conducted by Nosocomial Infection Control Committee. Surveillance were performed to patient in risk of nosocomial infections such as underwent surgical procedure, urinary catheter, peripheral or central venous catheter, ventilator and other invasive procedure. Criteria for nosocomial infection which were used, based on technical guidelines of nosocomial infection in Dr. Cipto Mangunkusumo National General Hospital, year 1999; which referred to CDC definition of nosocomial infections. Incidence rate of nosocomial infections in year 1999, 2000, 2001 and 2002 were 1.1, 0.9, 0.6 and $0.4 \%$ respectively. Type of nosocomial infection include catheter related, surgical wound, urinary tract and respiratory tract infections, ranged between 0 to $5.6 \%$. Gram negative bacteria consist of Pseudomonas sp, Enterobacter aerogenes, Escherichia coli, Proteus mirabilis were the most common nosocomial pathogen. Gram positive bacteria consist of Staphylococcus epidermidis, Staphylococcus aureus and Streptococcus anhemolyticus. Trend of increasing incidence of Gram positive nosocomial infection also showed in our surveillance. Mostly Gram negative bacteria had been resistant to penicillin, co amoxicillin-clavulanic acid and $3^{\text {rd }}$ generation cephalosporin, but still sensitive to $4^{\text {th }}$ generation cephalosporin and aminoglycoside. The Gram positive bacteria were still sensitive to penicillin, co amoxicillin-clavulanic acid, $4^{\text {th }}$ generation cephalosporin and aminoglycoside. (Med J Indones 2004; 13: 107-12)
\end{abstract}

Keywords : nosocomial infection, surveillance, resistance pattern

\footnotetext{
* Tropical and Infectious Diseases Division, Department of Medicine, Faculty of Medicine University of Indonesial Dr. Cipto Mangunkusumo National General Hospital, Jakarta, Indonesia

${ }^{f}$ Nosocomial Infection Control Committee Dr. Cipto Mangunkusumo National General Hospital, Jakarta, Indonesia
}

Nosocomial (hospital acquired) infection are one of the main problem in hospital which are associated with significant morbidity, mortality and increased economic cost. Incidence of hospital acquired infection ranged between 5 to 10 percent. ${ }^{1,2}$ The most common manifestation of nosocomial infections are urinary tract, surgical sites, pneumonia and blood stream infections. 
Formerly reported of incidence nosocomial infection in Dr. Cipto Mangunkusumo National General Hospital in year 1991-1996 were between 1.1 to $3 \%$. $^{3}$ Gram positive, gram negative, fungi or viral could be the caused of nosocomial infection but Gram negative bacteria such as Pseudomonas sp, E coli, Enterobacter, Proteus and Klebsiella still the most common pathogen. ${ }^{3}$ Increasing of emerging resistant pathogen such as Staphylococcus aureus resistant to methicillin, Enterococcus sp resistant to vancomycin, Pseudomonas aerouginosa resistant to ceftazidime / floroquinolones I carbapenem, Escherichia coli resistant to floroquinolones $/ 3^{\text {rd }}$ geneneration cephalosporines caused an implication in using advance generation of antibiotics and increasing the hospital cost. ${ }^{4}$

Surveillance should be attempted regularly to obtain local data of incidence of nosocomial infection, types of infection, pathogen and resistance pattern. We reported the results of nosocomial surveillance in Dr. Cipto Mangunkusumo National General Hospital in year 1999 to 2002 .

\section{METHODS}

The data were obtained from nosocomial surveillance, conducted by Nosocomial Infection Control Committee Dr. Cipto Mangunkusumo National General Hospital, Jakarta. Surveillance were performed to patient in risk of nosocomial infection such as underwent surgical procedure, urinary catheter, peripheral or central venous catheter, ventilator and other invasive procedure. Criteria for nosocomial infection which were used, based on technical guidelines of nosocomial infection in Dr. Cipto Mangunkusumo National General Hospital, year 1999 which referred to CDC definition of nosocomial infections. 5,6 Aerobe bacterial culture were performed to suspected sample such as blood, pus, urine and catheter in Clinical Pathology Department, Dr. Cipto Mangunkusumo National General Hospital. Incidence rate of infection was defined as number of infection divide by number of patient at risk; bacteriological and resistant pattern were presented as percentage.

\section{RESULTS}

In year 1999, 2000, 2001 and 2002 there were 377, 445,282 and 213 cases of nosocomial infections respectively; totally in 4 years duration there were 1317 cases. The most common cases were catheter related, surgical wound and urinary tract infections. (Table 1)

Table 1. Number of nosocomial infections according to types of infection in Cipto Mangunkusumo National General Hospital, Jakarta Year 1999-2002

\begin{tabular}{lrrrr}
\hline Type of infection & 1999 & 2000 & 2001 & 2002 \\
\hline Catheter related & 288 & 374 & 221 & 119 \\
Surgical wound & 36 & 11 & 34 & 45 \\
Urinary tract & 44 & 30 & 24 & 18 \\
Respiratory tract & 10 & 11 & 0 & 29 \\
All cases & 377 & 445 & 282 & 213 \\
\hline
\end{tabular}

Incidence rate of nosocomial infection in year 1999, 2000, 2001 and 2002 were 1.1, 0.9, 0.6 and $0.4 \%$ respectively. Incidence rate according to types of infection ranged between 0 to $5.6 \%$. (Table 2)

Table 2. Incidence rate (\%) of nosocomial infections according to types of infections in Cipto Mangunkusumo National General Hospital, Jakarta year 1999-2002

\begin{tabular}{lcccc}
\hline Type of infection & 1999 & 2000 & 2001 & 2002 \\
\hline Catheter related & 1.5 & 1.5 & 0.8 & 0.4 \\
Surgical wound & 0.5 & 0.1 & 0.4 & 0.5 \\
Urinary tract & 0.8 & 0.1 & 0.3 & 0.2 \\
Respiratory tract & 5.6 & 2.7 & 0 & 4.8 \\
All types & 1.1 & 0.9 & 0.6 & 0.4 \\
\hline
\end{tabular}

Pattern of microorganism isolate obtained from nosocomial infection showed that Gram negative bacteria were the most common pathogen. The most frequent of Gram negative bacteria were Pseudomonas sp, Enterobacter aerogenes, Escherichia coli, Proteus mirabilis; while Gram positive bacteria were Staphylococcus epidermidis, Staphylococcus aureus and Streptococcus anhemolyticus. Fungi (yeast) present in $0.4-0.5 \%$ isolates. (Table 3 )

According to type of isolates, Gram negative bacteria (Pseudomonas sp, Enterobacter sp, E coli) or Gram positive (Staphylococcus epidermidis, Streptococcus anhemolyticus) could be found from blood, pus, urine, iv catether or sputum. (Table 4)

Resistance pattern of some important species of Gram negative and Gram positive bacteria to beta-lactam and aminoglycoside showed in Table 5 and 6. 
Table 3. Bacterial pattern (\%) from nosocomial infections isolates in Dr. Cipto Mangunkusumo National General Hospital, Jakarta year $1999-2002$

\begin{tabular}{lcccc}
\hline & \multicolumn{3}{c}{ percent } \\
\cline { 2 - 5 } Year & $\begin{array}{c}1999 \\
(\mathrm{n}=253)\end{array}$ & $\begin{array}{c}2000 \\
(\mathrm{n}=369)\end{array}$ & $\begin{array}{c}2001 \\
(\mathrm{n}=182)\end{array}$ & $\begin{array}{c}2002 \\
(\mathrm{n}=122)\end{array}$ \\
\hline Pseudomonas sp & 41.1 & 39.8 & 56.4 & 42.6 \\
Enterobacter aerogenes & 22.5 & 20.1 & 9.8 & 23.8 \\
Escherichia coli & 20.2 & 15.7 & 13.7 & 11.5 \\
Acinetobacter calcoa & 1.2 & 0.8 & - & 7.3 \\
Klebsiella sp & 1.6 & 3.0 & 1.1 & 1.6 \\
Proteus mirabilis & 2.4 & 1.6 & 4.9 & 0.8 \\
Proteus morganili & - & 0.3 & - & - \\
Proteus vulgaris & 0.8 & 0.8 & - & 2.4 \\
Fungi (yeast) & 0.4 & 0.5 & - & 2.5 \\
Staphylococcus epidermidis & 6.3 & 12.5 & 8.2 & - \\
Staphylococcus aureus & 1.2 & 2.2 & 1.6 & 1.6 \\
Streptococcus anhemolyticus & 2.0 & 1.1 & 0.5 & 0.8 \\
Streptococcus hemolytic & 0.4 & 1.1 & 1.1 & - \\
Staphylococcus albus & - & 0.5 & - & 5.1 \\
Others & - & - & 2.7 & \\
\hline
\end{tabular}

Table 4. Bacterial isolate according to type of specimen from nosocomial infection in Dr. Cipto Mangunkusumo National General Hospital, Jakarta, 1999 - 2002

\begin{tabular}{lrrrrr}
\hline Type of isolate & Blood & Pus & Urine & iv cath & Others \\
\hline Pseudomonas sp & 115 & 31 & 32 & 24 & 211 \\
Enterobacter aerogenes & 36 & 20 & 29 & 6 & 67 \\
Escherichia coli & 43 & 31 & 49 & 3 & 21 \\
Acinetobacter calcoa & 10 & - & - & 1 & 4 \\
Klebsiella sp & 3 & 3 & 4 & - & 9 \\
Proteus mirabilis & 8 & 7 & 6 & - & - \\
Proteus morganili & - & 1 & - & - & - \\
Proteus vulgaris & - & 2 & 2 & - & 1 \\
Fungi (yeast) & 2 & 1 & 1 & - & 14 \\
Staphylococcus epidermidis & 48 & - & 5 & - & 9 \\
Staphylococcus aureus & - & 4 & 1 & - & 2 \\
Streptococcus anhemolytic & 10 & - & - & - & - \\
Streptococcus hemolytic & 4 & 1 & 3 & - & - \\
Staphylococcus albus & - & 1 & 1 & 1 & 1 \\
Others & 6 & 0 & 3 & 48 & 349 \\
Total & 285 & 102 & 136 & & \\
\hline
\end{tabular}


Mostly Gram negative bacteria had been resistant to penicillin, co amoxicillin-clavulanic acid and $3^{\text {rd }}$ generation cephalosporin, but still sensitive to $4^{\text {th }}$ generation cephalosporin and aminoglycoside. Pseudomonas sp. had been resistant to penicillin, $3^{\text {rd }}$ generation cephalosporin and netromycin and Klebsiella sp. to penicillin, cefotaxime, cefotiam and gentamycin.
Resistance pattern for Gram positive bacteria showed that Staphylococcus epidermidis and Staphylococcus aureus were still sensitive to penicillin, co amoxicillinclavulanic acid, $4^{\text {th }}$ generation cephalosporin and aminoglycoside. (Table 6)

Table 5. Resistance pattern (\%) of important Gram negative bacteria from nosocomial infections isolate in Dr. Cipto Mangunkusumo National General Hospital, Jakarta, year 2001 and 2002

\begin{tabular}{lrrrrrrrrrr}
\hline & \multicolumn{2}{c}{ Pseudomonas } & \multicolumn{2}{c}{ Enterobacter } & \multicolumn{2}{c}{ E.coli } & \multicolumn{2}{c}{ Acinetobacter } & \multicolumn{2}{c}{ Klebsiella } \\
\cline { 2 - 10 } & 2001 & 2002 & 2001 & 2002 & 2001 & 2002 & 2001 & 2002 & 2001 & 2002 \\
\hline \multirow{2}{*}{ Ampicillin } & 100 & 100 & 100 & 100 & 95 & 100 & $\mathrm{Nd}$ & 100 & 100 & 100 \\
Sulbenicillin & 89 & 77 & 100 & 93 & 91 & 93 & $\mathrm{Nd}$ & 100 & 0 & $\mathrm{Nd}$ \\
Co-amoxiclav & 97 & $\mathrm{Nd}$ & 100 & $\mathrm{Nd}$ & 93 & 92 & $\mathrm{Nd}$ & $\mathrm{Nd}$ & 100 & $\mathrm{Nd}$ \\
Cefotiam & 100 & 100 & 78 & 90 & 68 & 64 & 100 & 100 & 0 & 100 \\
Cefotaxime & 100 & 84 & 100 & 70 & 100 & 50 & $\mathrm{Nd}$ & 100 & 100 & 100 \\
Cefepime & 65 & 50 & 44 & 38 & 36 & 21 & $\mathrm{Nd}$ & 45 & 0 & 0 \\
Gentamycin & 82 & 77 & 100 & 100 & 95 & 100 & $\mathrm{Nd}$ & 100 & 100 & 100 \\
Netromycin & 100 & $\mathrm{Nd}$ & 100 & 93 & 91 & 93 & $\mathrm{Nd}$ & 100 & 0 & $\mathrm{Nd}$ \\
Amikacin & 80 & 60 & 28 & 14 & 14 & 72 & $\mathrm{Nd}$ & 89 & 0 & 0 \\
\hline
\end{tabular}

Nd ; No data

Table 6. Resistance pattern (\%) of important Gram positive bacteria from nosocomial infections isolate in Dr. Cipto Mangunkusumo National General Hospital, Jakarta, year 2001 and 2002

\begin{tabular}{|c|c|c|c|c|c|c|}
\hline & \multicolumn{2}{|c|}{ Staph epid } & \multicolumn{2}{|c|}{ Staph aureus } & \multicolumn{2}{|c|}{ Strep anhemolytic } \\
\hline & 2001 & 2002 & 2001 & 2002 & 2001 & 2002 \\
\hline Ampicillin & 92 & 33 & 67 & $\mathrm{Nd}$ & 0 & 50 \\
\hline Sulbenicillin & 69 & 33 & 67 & $\mathrm{Nd}$ & 0 & 100 \\
\hline Co-amoxyclav & 83 & $\mathrm{Nd}$ & 50 & $\mathrm{Nd}$ & 0 & $\mathrm{Nd}$ \\
\hline Cefotiam & 100 & 0 & 33 & $\mathrm{Nd}$ & 0 & 0 \\
\hline Cefotaxime & 100 & 0 & 100 & $\mathrm{Nd}$ & 0 & 100 \\
\hline Cefepime & 30 & 33 & 33 & $\mathrm{Nd}$ & 0 & 0 \\
\hline Gentamycin & 38 & 33 & 33 & $\mathrm{Nd}$ & 100 & 100 \\
\hline Netromycin & 78 & $\mathrm{Nd}$ & 78 & $\mathrm{Nd}$ & 100 & $\mathrm{Nd}$ \\
\hline Amikacin & 23 & 0 & 0 & $\mathrm{Nd}$ & 100 & 0 \\
\hline
\end{tabular}

Nd ; No data 


\section{DISCUSSION}

Incidence of nosocomial infection could be different among hospitals or specific care units. The risk of nosocomial infection were associated with hospital type (general or private), patients (medical, surgical, burn, critical care, cancer or immunocompromized), length of stay and standard procedure in handling patients by health care workers.

Incidence of nosocomial infection in Dr. Cipto Mangunkusumo National General Hospital in 1999 to 2002, were ranged between 0.1 to $5.6 \%$. It seems comparable to National Nosocomial Infections Surveillance (NNIS) in 2003 report that percentile 50 incidence of nosocomial infection ranged between 2.2 to $7.3 \% .^{9}$ The incidences tend to decrease in the last 2 years from 1.1 to $0.4 \%$. The most common infections were catheter related; but respiratory tract infection in ventilator used patients was in the highest rate.

Incidence of nosocomial infection in surgical site, was ranged between 0.1 to $0.5 \%$. This surveillance didn't specified surgical site infection by type of surgical procedure which probably different. The risk of infection will be lower in clean, simple and rapid procedure but higher in dirty wound or complicated procedure. $^{10,11}$ Our surveillance only performed in patient who underwent clean and clean contaminated type operations.

Pattern of nosocomial infection was still dominated by Gram negative bacteria. The most common pathogens were Pseudomonas sp, Enterobacter aerogenes, Escherichia coli, Acinetobacter calcoa, Proteus mirabilis, Klebsiella sp, Staphylococcus epidermidis, Streptococcus anhemolytic and Staphylococcus aureus. These pathogen mostly isolated from blood, urine and pus. Blood stream infection of these pathogen was potentially cause sepsis and septic shock. ${ }^{12}$ The trend of increasing incidence of Gram positive nosocomial infection also showed in our surveillance. ${ }^{13}$

Resistance of Gram negative bacteria to penicillin, co amoxicillin-clavulanic acid and $3^{\text {rd }}$ generation cephalosporin seems to be a major problem in the treatment of nosocomial infection. These antibiotics had been widely used in daily clinical practice and potentially caused growth of resistant pathogen in hospital. Mostly nosocomial pathogen remain sensitive to $4^{\text {th }}$ generation cephalosporin and aminoglycoside, but the usage of these agents should be selected to clearly indicated patients.
Emerging resistant pathogens like E. coli, Klebsiella pneumonia, Pseudomonas and Enterobacter resistant to $3^{\text {rd }}$ generation cephalosporin had reported in our surveillance, comparable to NNIS surveillance that ranged between 6.3 to $32 \%$. $^{9}$ Another emerging resistant pathogens like MRSA, VRE and ESBL which was not evaluated in our surveillance, should be reported in the next surveillance.

\section{CONCLUSION}

Incidence rate of nosocomial infections in Dr. Cipto Mangunkusumo National General Hospital, in year 1999, 2000, 2001 and 2002 were 1.1, 0.9, 0.6 and $0.4 \%$ respectively. Type of nosocomial infection include catheter related, surgical wound, urinary tract and respiratory tract infections ranged between 0 to $5.6 \%$. Gram negative bacteria consist of Pseudomonas sp, Enterobacter aerogenes, Escherichia coli, Proteus mirabilis were the most common nosocomial pathogen. Gram positive bacteria consist of Staphylococcus epidermidis, Staphylococcus aureus and Streptococcus anhemolyticus. Trend of increasing incidence of Gram positive nosocomial infection also showed in our surveillance. Mostly Gram negative bacteria had been resistant to penicillin, co amoxicillin-clavulanic acid and $3^{\text {rd }}$ generation cephalosporin, but still sensitive to $4^{\text {th }}$ generation cephalosporin and aminoglycoside. The Gram positive bacteria were still sensitive to penicillin, co amoxicillin-clavulanic acid, $4^{\text {th }}$ generation cephalosporin and aminoglycoside.

\section{REFERENCES}

1. Wenzel RP. Management principles and the infection control committee. In: Wenzel RP, editor. Prevention and control of nosocomial infection. $2^{\text {nd }}$ ed. Baltimore: William \& Wilkins; 1993. p.207-13.

2. Burke JP. Infection Control, a problem for patient safety. N Eng J Med 2003;348(7):651-6.

3. Widodo D, Astrawinata D, Tumbelaka A. Kuman penyebab infeksi nosokomial dan pola kepekaannya terhadap antibiotik di RSUPN Dr. Cipto Mangunkusumo. Maj Kedokt Indon;48(12):478-82.

4. Weinstein RA. Nosocomial infection update. Emerg Infec Dis [serial online] 1998 July-Sept cited 1998 Nov 17]; 4(3): Available from : URL:http//www.cdc.gov/cidod/eid/ vol4no3/veinstein.htm.

5. Panitia Pengendalian Infeksi Nosokomial RSUPN Dr. Cipto Mangunkusumo. Buku pedoman dan petunjuk teknis infeksi nosokomial; 1999. 
6. Garner JS, Jarvis WR, Emori TG, Horan TC, Hughes JM. CDC definition for nosocomial infections. In: Olmsted $\mathrm{RN}$, ed. APIC infection control and applied epidemiology: priciples and practice. St Louis: Mosby;1996. p. A1-20.

7. Burke JP, Riley DK, Wong SW, et al. Epidemiology and prevention of nosocomial infection of organ system. In: Mayhall CG, ed. Hospital epidemiology and infection control. Baltimore: William\&Wilkins;1996. p. 139-270.

8. Sax H, Pittet D, Swiss-NOSO Network. Interhospital differences in nosocomial infection rates: important of case-mix adjustment. Arch Intern Med 2002;162(21): 2437-42.

9. Division of Heath care Quality Promotion, National Center for Infectious Diseases, Centers for Diseases Control and Prevention, Public Health Service, US Department of Health and Human Services. National Nosocomial Infections Surveillance (NNIS) system report, data summary from January 1992 trough June 2003, issued August 2003. Am J Infec Control 2003;31:481-98.
10. Thibon P, Parienti JJ, Borgey F, Le Prieur A. Barnet C, Brager $\mathrm{P}$, et al. Use censored data to monitor surgical site infections. Infec Control Hosp Epidemiol 2002; 23 (7); 368-71.

11. Mangram AJ, Horan TC, Pearson ML, Silver LC, Jarvis WR, The Hospital Infection Control Practice Advisory Committee. Guidelines for prevention surgical site infection, 1999. Infec Control Hosp Epidemiol, 1999; 20(4): 247-78.

12. Hugonnet S, Sax H, Eggimann P, Chevrolet JC, Pittet D. Nosocomial bloodstream infection and clinical sepsis. Emerg Infec Dis 1998 [serial online] 2004 Jan [cited 2004 Febr 12];10(1) : Available from : URL: http//www.cdc.gov/ncidod/eid/vo10no1/03-0407.htm.

13. Pittet D, Wenzel RP. Nosocomial bloodstream infections. Secular trends in rates, mortality, and contribution to total hospital deaths. Arch Intern Med 1995; 155(11): 1177-84. 